The incidence of the $\alpha$-thalassaemia gene in Africa still remains unsettled. Most studies have used the presence of Hb Bart's in cord blood as the index. Esan (1972) pointed out, however, that in a survey of 1,816 Nigerian cord bloods the presence or absence of $\mathrm{Hb}$ Bart's did not correlate with the haematological features expected in an $\alpha$-thalassaemia. This contrasted with the findings of another large study by Weatherall (1963) who found the incidence was $2 \%$ in 900 cord blood samples of American Negroes, where it was always associated with signs of thalassaemic disorder. Our own observation that trace amounts of $\mathrm{Hb}$ Bart's are a feature of the present patients would support this. Thalassaemia syndromes like $\mathrm{Hb} \mathrm{H}$ disease are rare in Africa, though it has been reported (Barclay et al., 1969) that Bart's hydrops fetalis syndrome has not yet been described. Schwartz and Atwater (1972) conclude that their findings may be due to the benign expression of the $\alpha$-thalassaemia gene in their patients. Certainly their data on the haematological picture of the $\alpha$-thalassaemia trait would make this condition difficult to diagnose without biosynthetic studies.

From our results it also appears that the interaction of $\alpha-$ thalassaemia with homozygous sickle-cell disease does not result in the picture typical of $\alpha$-thalassaemia seen in other ethnic groups, nor, and perhaps more relevant to this study, does the presence of the gene modify the haematological features one would expect with typical homozygous sickle-cell disease, except for the mean corpuscular haemoglobin concentration.

In both patients the mean corpuscular haemoglobin concentration was below normal levels. This single index might provide an explanation for their relatively benign clinical status. May and Huehns (1972) have shown that by artificially lowering the haemoglobin concentrations of cells containing $\mathrm{Hb} \mathrm{S}$, the degree of protein-protein interaction and sickling is lessened. $\alpha$-Thalassaemia gene might have the same effect by lowering in vivo the intracellular haemoglobin concentration.

This is the first time that $\alpha$-thalassaemia has been shown incontrovertibly in West Africa. It seems that biosynthetic studies are required to enable this to be done because the electrophoretic and haematological evidence is minimal. The examination of globin chain synthesis of children born with $\mathrm{Hb}$ Bart's in their cord blood and of their parents might establish the true incidence of $\alpha$-thalassaemia. It will also be important to examine the globin chain synthesis of other sicklecell anaemia patients who show an unusually benign clinical course.

The inclusion bodies in the present patients require some comment. Inclusion bodies were noted in sickle-cell anaemia erythrocytes by Lehmann (1969) who suggested that they might be $\alpha$-chain precipitates and contribute to the shortened life span of the red cells. White (1972) has indeed observed free $\alpha$-chains in biosynthetic experiments on sickle-cell anaemia reticulocytes, but they were not a constant finding either in all patients or at all times in the same patients. Schneider et al. (1972) described inclusion bodies in cells containing $\mathrm{Hb} S$ or $\mathrm{Hb} \mathrm{C}$, and the inclusion bodies seen in the peripheral blood of the two women reported here resembled those described. As they are associated with $\alpha$-thalassaemia it is most unlikely that they are $\alpha$-chain precipitates. On the other hand if ordinary sickle-cell anaemia patients can experience a surplus of $\alpha$-chains even irregularly, $\alpha$-thalassaemia trait would obviously be advantageous to them. But much more work will have to be done on the biosynthesis of $\mathrm{Hb} \mathrm{S}$ in anaemia, other sickle-cell disease states, and the trait, before it will be possible to generalize about the role of $\alpha$-thalassaemia in populations in which sickling is frequent.

\section{References}

Apthorp, G. H., Measday, B., and Lehmann, H. (1963). Lancet, 1, 1344 Barclay, G. P.' T., Charlesworth, D., and Lehmann, H. (1969). British Medical fournal, 4, 595.

Betke, K., Marti, H. R., and Schlicht, I. (1959). Nature, 184, 1877.

Charache, S., and Conley, C. L. (1964). Blood, 24, 25.

Clegg, J. B., Naughton, M. A., and Weatherall, D. J. (1966). Fournal of Molecular Biology, 19, 91.

Dacie, J. V., and Lewis, S. M. (1968). Practical Haematology, 4th edn. London, Churchill.

Esan, G. S. F. (1972). British fournal of Haematology, 22, 75

Huehns, E. R., Flynn, F. V., Butler, E. A., and Shooter, E. M. (1960). British fournal of Haematology, $6,388$.

Huisman, T. H. J., and Dozy, A. M. (1965). fournal of Chromatography, 19, 160.

Jackson, J. F., Odom, J. L., and Bell, W. N. (1961). Fournal of the American Medical Association, 177, 867.

Konotey-Ahulu, F. I. D. (1971). M.D. Thesis, London University.

Kraus, L. M., Miyaji, T., Iuchi, I., and Kraus, A. P. (1966). Biochemistry, 5, 3701 .

Lehmann, H. (1969). Blood, 34, 732.

Lingrel, I. B., and Borsook, H. (1963). Biochemistry, 2, 309.

Marengo-Rowe, A. J. (1965). fournal of Clinical Pathology, 18, 790

May, A., and Huehns, E. R. (1972). In Internationales Symposium, Synthese, Struktur und Funktion des Hämoglobins, Bad Nauheim, 22-24 April 1971, ed. H. Martin and L. Nowicki, p. 279. Munich, Lehmann.

Nierhaus, K., and Betke, K. (1968). Klinische Wochenschrift, 46, 47.

chneider, R. G., Takeda, I., Gustavson, L. P., and Alperin, J. B. (1972). Nature, 235, 88.

Schwartz, E., and Atwater, J. (1972). fournal of Clinical Investigation, 51,

Serjeant, G. R., Richards, R., Barbor, F. R. H., and Milner, P. F. (1968). British Medical fournal, 3, 86.

Serjeant, G. R., Ashcroft, K., Serjeant, B. R., and Milner, P. F. (1973). British fournal of Haematology. In press.

Weatherall, D. J. (1963). British fournal of Haematology, 9, 265.

Weatherall, D. J., Clegg, J. B., Blankson, J., and McNeil, S. (1969). British fournal of Haematology, 17, 517.

White, J. M. (1972). Biochimic. In press.

\title{
Procaine in Malignant Hyperpyrexia
}

\author{
R. F. W. MOULDS, M. A. DENBOROUGH
}

Lignocaine, on the other hand, produces a variable response and sometimes increases the contracture.

The muscle from a patient with an inherited susSummary

The caffeine contracture of normal human muscle, which has been used as a model for malignant hyperpyrexia, is greatly potentiated by halothane. Prior administration of procaine markedly reduces the halothane-potentiated caffeine contracture, and procaine given at the height of the contracture induces relaxation.

University of Melbourne Department of Medicine, Royal Melbourne Hospital, Victoria, Australia 3050

R. F. W. MOULDS, M.B., B.MED.scI., Research Fellow

M. A. DENBOROUGH, M.D., F.R.A.C.P., Reader in Medicine ceptibility to malignant hyperpyrexia contracted spontaneously with halothane alone, and this contracture was reversed by procaine.

These experiments support the therapeutic use of procaine in malignant hyperpyrexia.

\section{Introduction}

Since malignant hyperpyrexia was first reported (Denborough and Lovell, 1960; Denborough et al., 1962) it has become clear 
that patients at risk of developing this complication of anaesthesia have a myopathy, which may be subclinical (Denborough et al., 1970a; Isaacs and Barlow, 1970; King et al., 1972). Hypertonicity of voluntary muscles is a prominent clinical feature of malignant hyperpyrexia, and this is followed by enzyme changes indicating severe muscle damage (Denborough et al., 1970b). This muscular rigidity is probably due to a high calcium ion concentration in the myoplasm (Britt and Kalow, 1970; Denborough et al., 1971).

Caffeine causes contracture of skeletal muscle. Its mechanism of action is twofold in that it both stimulates the release of calcium ions from the sarcoplasmic reticulum, thus initiating contracture, and also blocks the re-uptake of calcium by the sarcoplasmic reticulum, thus preventing subsequent relaxation (Weber and Herz, 1968; Weber, 1968). Muscle from survivors of malignant hyperpyrexia has been found to react to caffeine with an increased contracture, and this effect is potentiated by halothane (Kalow et al., 1970).

Because the effect of caffeine on frog skeletal muscle is blocked by local anaesthetics (Feinstein, 1963), procaine has been suggested for the treatment of malignant hyperpyrexia (Strobel, 1971; Harrison, 1971; Relton et al., 1972). There is some evidence to suggest that procaine prevents the development of malignant hyperpyrexia in susceptible Landrace pigs (Harrison, 1971), though attempts to confirm this have not been successful (Hall et al., 1972). Procaine also blocks the halothanepotentiated caffeine contracture of frog skeletal muscle (Strobel and Bianchi, 1971).

In the present study the effect of procaine has been examined on both the halothane-potentiated caffeine contracture of normal human muscle and on the halothane-induced contracture of muscle from a patient susceptible to malignant hyperpyrexia.

\section{Materials and Methods}

Strips of human rectus abdominis muscle, about $4-\mathrm{cm}$ long by $1-\mathrm{cm}$ wide, were obtained from patients having elective abdominal surgery.

'The patient with the inherited susceptibility to malignant hyperpyrexia was the paternal aunt of the original propositus, and has been reported on previously (Denborough et al., 1970a). At the time of the present study she was 71 and in her family she is the person most severely affected by the myopathy. Her preoperative serum creatine phosphokinase level was 224 IU/1. (normal range 0-55). She had a hysterectomy and bilateral salpingo-oophorectomy for fibroids and an ovarian dermoid cyst. Premedication was $10 \mathrm{mg}$ diazepam given intramuscularly and she was given a spinal anaesthetic with $1.8 \mathrm{ml}$ of heavy Nupercaine (cinchocaine) with supplementary thiopentone, nitrous oxide, and oxygen.

None of the other patients had evidence of muscle disease. All but two were given general anaesthetics, consisting of thiopentone, nitrous oxide, and a muscle relaxant-either succinylcholine, tubocurarine, gallamine, or pancuronium. Premedication was either morphine or atropine, or papaveretum (Omnopon-Scopolamine). One patient was given a spinal anaesthetic supplemented by nitrous oxide and thiopentone; and another had a field block using $2 \%$ lignocaine with adrenaline.

The strips of muscle were taken straight to the laboratory from the operating theatre in $100 \mathrm{ml}$ of Ringer's solution, containing sodium, potassium, calcium, magnesium, chloride, phosphate, bicarbonate, and glucose in concentrations resembling those in human serum. Preparations of the muscle were made using small strips about $2 \mathrm{~cm}$ long and $4 \mathrm{~mm}$ wide, and were ready for the first test within 15 minutes of removal from the patient.

The strips were immersed in a bath of $25 \mathrm{ml}$ of the Ringer's solution at $37^{\circ} \mathrm{C}$. Oxygen containing $5 \%$ carbon dioxide was bubbled through the solution which then had a pH of about 7-2. The resting tension used was $1 \mathrm{~g}$, and isometric tension was measured using a force transducer connected to an amplifier and then a continuous recorder. The drugs were added to the bath solution by disposable syringe and halothane was added by passing the carbogen sequentially through two flasks, each containing $500 \mathrm{ml}$ of an $18-\mathrm{mM}$ solution of halothane in water, before it was bubbled into the muscle bath solution.

Caffeine was added in increasing concentrations at intervals of four minutes, and the contracture was measured as the maximum tension produced during that interval by each concentration of caffeine. The run was concluded when the muscle went into continuous rigor.

At least two preparations were made from each piece of muscle, one being used as a control, the other to test the drugs. The preparations slowly deteriorated with time when stored at $4^{\circ} \mathrm{C}$ in the bath solution, so they were randomly allocated to two groups. In one group the control was done before using the drugs, in the other the control was done last. The procaine and lignocaine were prepared as $10 \%$ solutions of procaine hydrochloride or lignocaine hydrochloride in $0.1 \%$ sodium metabisulphite.

\section{Results}

Initial experiments were performed to confirm that halothane potentiated the caffeine contracture. Different pieces of muscle varied considerably in their response, both in the magnitude of contracture and in the concentrations of caffeine which first initiated contracture. The contracture in the presence of halothane was always better than with caffeine alone (Fig. 1). Halothane alone never caused contracture in normal muscle.

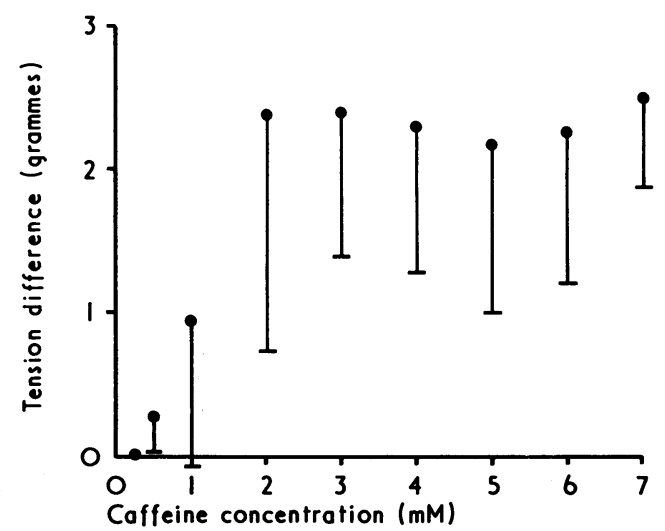

FIG. 1-Difference in contracture between muscle stimulated by caffeine alone and muscle stimulated by caffeine in the presence of halothane. alone and muscle stimulated by caffeine in the presence of halothane. bar represents a lower $5 \%$ confidence limit for mean difference, based on the $t$ distribution; if bar does not intersect horizontal axis significance at $5 \%$
a r $t$ distribution; if
level is indicated.

The effect of procaine on the caffeine-induced contracture alone was variable. There was a strong suggestion that the contractures were less in the presence of $5 \mathrm{mM}$ procaine, but the difference between them was not statistically significant. The halothane-potentiated caffeine contracture was markedly inhibited by the earlier administration of $5 \mathrm{mM}$ procaine (Fig. 2). A 5-mM procaine solution was also added to each piece of muscle when a large enough concentration of caffeine had been reached to cause a continuous rigor. This was found by experience to be when the muscle was still contracting four minutes after the addition of the last concentration of caffeine. In al instances the procaine either slowed the rate of contracture, or, as was usually the case, brought about immediate slow relaxation, but this relaxation was never complete. A representative example is shown in Fig. 3. The effect of lignocaine was variable and unpredictable. In some cases halothane and lignocaine alone produced contracture, thus augmenting the caffeine contracture 
at low concentrations. At higher caffeine concentrations, lignocaine seemed to inhibit the contracture.

The muscle from the patient susceptible to malignant hyperpyrexia contracted in response to halothane alone, and this contracture was partly reversed by $5 \mathrm{mM}$ procaine (Fig. 4). In normal muscle halothane alone did not induce muscle contracture, regardless of whether the patient had been given either a muscle relaxant or spinal or local anaesthetic.

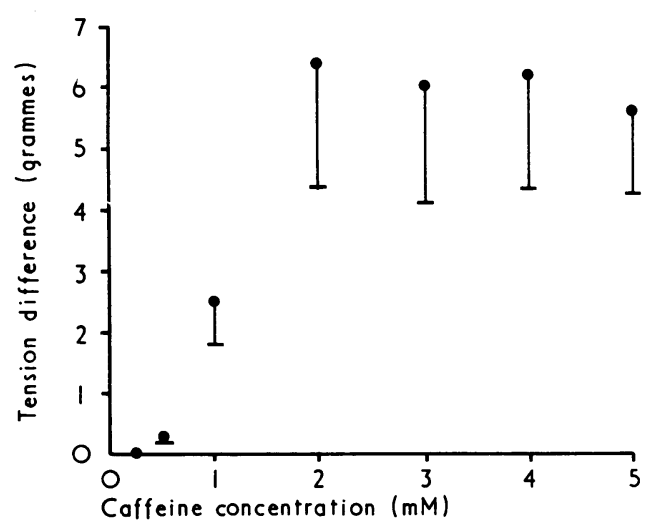

FIG. 2-Inhibition of halothane-potentiated caffeine contracture by $5 \mathrm{mM}$ procaine hydrochloride. Vertical axis represents difference between contractures in presence and absence of procaine. $9=$ Mean of eight experiments on different pieces of normal muscle. Vertical bar represents a lower $5 \%$ confidence limit for mean difference, based on the $t$ distribution; if bar does not intersect horizontal axis significance at $5 \%$ level is indicated.

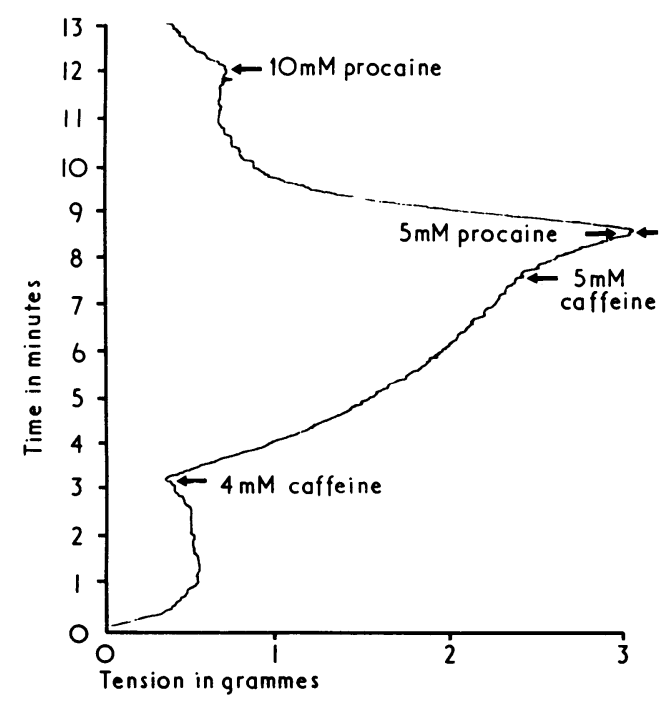

FIG. 3-Example of experiment showing reversal of halothane-potentiated caffeine contracture by procaine.

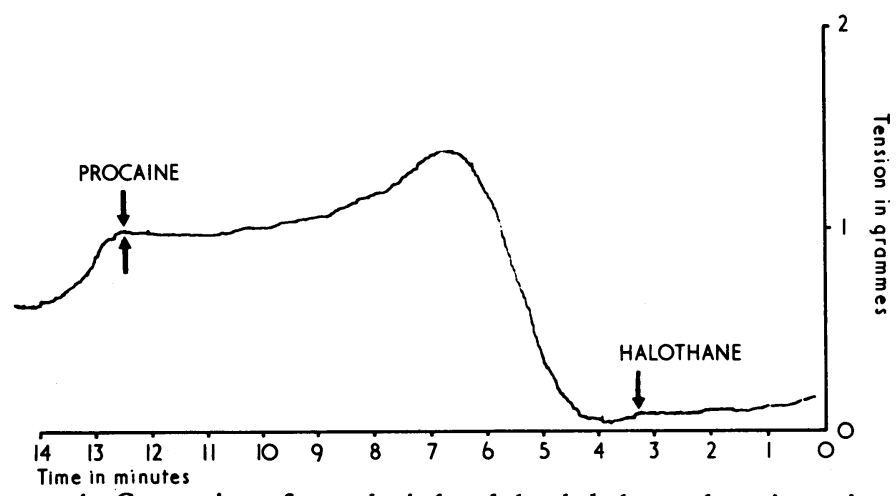

FIG. 4 Contraction of muscle induced by halothane alone in patient susceptible to malignant hyperpyrexia, and its reversal by $5 \mathrm{mM}$ procaine hydrochloride.
In the patient susceptible to malignant hyperpyrexia, the caffeine contracture alone was greater than normal at low caffeine concentrations but fell within the normal range at higher concentrations. The caffeine contracture was potentiated by low concentrations of halothane but at the higher concentrations of halothane, which greatly enhance the caffeine contracture in normal muscle, the malignant hyperpyrexia muscle failed to contract with caffeine.

\section{Discussion}

The findings in the present investigation support the use of procaine in the treatment of malignant hyperpyrexia in man. Just as procaine inhibits the development of malignant hyperpyrexia in Landrace pigs (Harrison, 1971), and procainamide prevents halothane-potentiated caffeine contracture in frog sartorius muscle (Strobel and Bianchi, 1971), so the present study has shown that procaine inhibits the development of halothanepotentiated caffeine contracture in man.

More important is the finding in the present investigation that procaine regularly reverses the established halothane-potentiated caffeine contracture in man. The relevance of this to malignant hyperpyrexia has also been demonstrated by showing that procaine reverses the halothane-induced muscle contracture in a patient susceptible to malignant hyperpyrexia. The finding in the present investigation that halothane alone induced muscle contracture in a patient susceptible to malignant hyperpyrexia has been reported previously (Ellis et al., 1971), but differs from the observations of Kalow et al. (1970).

As the muscular rigidity, fever, and metabolic acidosis in malignant hyperpyrexia all probably have the same basis, this being a high calcium ion concentration in the myoplasm (Britt and Kalow, 1970; Denborough, et al., 1971), the fact that procaine reverses the muscular rigidity makes it reasonable to expect that procaine may also reverse the other clinical features of the syndrome.

Although it would require a dose of about $6.8 \mathrm{~g}$ of procaine hydrochloride to achieve a concentration of $5 \mathrm{mM}$ in the circulation in man, our own results suggest that the effect of procaine is dose dependent, and give weight to the regimen of procaine administration which has been previously recommended for malignant hyperpyrexia in man (Relton et al., 1972).

R. F. W. Moulds is a postgraduate research scholar of the National Health and Medical Research Council. We are indebted to Dr. J. S. Maritz for advice, and to the many surgeons who provided us with muscle samples.

\section{References}

Britt, B. A., and Kalow, W. (1970). Canadian Anaesthetists' Society fournal,

17, 316. Lancet, 1, 1138.

Denborough, M. A., Forster, J. F. A., Hudson, M. C., Carter, N. G., and Zapf, P. W. (1970b). Lancet, i, 1137 .

Denborough, M. A., Forster, J. F. A., Lovell, R. R. H., Maplestone, P. A., and Villiers, J. D. (1962). British fournal of Anaesthesia, 34, 395.

Denborough, M. A., et al. (1971). Paper read at International Symposium on Malignant Hyperthermia held in Toronto, 1971. In press.

Denborough, M. A., and Lovell, R. R. H. (1960). Lancet, $2,45$.

Ellis, F. R., Harriman, D. G. F., Keaney, N. P., Kyei-Mensah, K., and Tyrell, J. H. (1971). British fournal of Anaesthesia, 43, 721.

Feinstein, M. B. (1963). Fournal of General Phsyiology, 47, 151.
Hall, L. W., Trim, C. M., and Woolf, N. (1972). British Medical fournal 2,145 .

Harrison, G. G. (1971). British Medical fournal, 3, 454.

Isaacs, H., and Barlow, M. B. (1970). British Medical fournal, 1, 275.

Kalow, W., Britt, B. A., Terreau, M. E., and Haist, C. (1970). Lancet, 2, 895

King, J. O., Denborough, M. A., and Zapf, P. W. (1972) Lancet, 1, 365.

Relton, J. E. S., Steward, D. J., Creighton, R. E., and Britt, B. A. (1972). Canadian Anaesthetists' Society fournal, 19, 200.

Strobel, G. E. (1971). Lancet, 1, 40.

Strobel, G. E., and Bianchi, C. P. (1971). Anesthesiology, 35, 465.

Weber, A. (1968). Fournal of General Physiology, 52, 760.

Weber, A., and Herz, R. J. (1968). Journal of General Physiology, 52, 750. 